\title{
Rating Risk Rating Systems
}

\author{
Suhejla Hoti \\ Department of Economics, University of Western Australia (shoti@ecel.uwa.edu.au)
}

\begin{abstract}
In light of the tumultuous events flowing from 11 September 2001, the risks associated with engaging in international relationships have increased substantially, and become more difficult to analyse and predict for decision makers in the economic, financial and political sectors. The importance of country risk analysis is underscored by the existence of several prominent country risk rating agencies, namely the Economist Intelligence Unit, Euromoney, Institutional Investor, International Country Risk Guide, Moody’s, Political Risk Services, and Standard and Poor's. These risk rating agencies employ different methodologies and methods to determine country risk ratings, combining a wide range of qualitative and quantitative information regarding alternative measures of economic, financial and political risk into associated composite risk ratings. However, the accuracy of any risk rating agency with regard to any or all of these measures is open to question. For this reason, the paper provides a qualitative comparison of country risk rating systems used by these seven leading rating agencies. Such an evaluation permits a critical assessment of the importance and relevance of agency rating systems.
\end{abstract}

Keywords: Country risk; rating agencies; risk rating systems; economic risk; financial risk; political risk; composite risk; component analysis; qualitative comparison.

\section{INTRODUCTION}

Country risk has become a topic of major concern for the international community in the last two decades. The debt crises of the early 1980s, political changes that occurred in the former Communist Block countries in the late 1980s and early 1990s, the East Asian and East European financial crises that have occurred since 1997, the recent financial and banking crises in Argentina, and finally the events of 11 September 2001 and their aftermath, clearly show that the risks associated with engaging in international relationships have increased substantially. Such events have also become more difficult to analyse and predict for decision makers in the economic, financial and political sectors.

The increasing importance of country risk analysis by both official and private institutions is due to the fact that the globalisation of world trade and open capital markets are risky elements that can cause financial crises with rapid contagion effects, which threaten the stability of the international financial sector (Hayes, 1998). Furthermore, the increasing number of financial crises in developing countries, and their associated costs to the official institutions and private entities, are also major factors of risk that need to be considered.
Given these developments, the activities of country risk rating agencies have increased substantially over the last two decades. Rating agencies compile country risk ratings as measures of the ability and willingness of countries to service their financial obligations. This is of particular importance for developing countries, for which there is limited information available. Country risk ratings help developing countries to gain access to capital markets and provide economic, financial and political operators with essential tools to assess and manage such risk. Consequently, the accuracy of risk rating agencies with regard to any or all country risk measures is crucial.

The plan of the paper is as follows. Section 2 presents the nature of the country risk rating industry. Section 3 discusses the empirical findings of 50 published studies on country risk that were reviewed in Hoti (2002). The country risk rating systems of seven leading commercial analysts of country risk, namely Institutional Investor, Euromoney, Moody's, Standard and Poor's, International Country Risk Guide, and Political Risk Services, are assessed and compared in Section 4. Some concluding remarks are given in Section 5. 


\section{COUNTRY RISK RATINGS}

The importance of country risk analysis is underscored by the existence of several prominent country risk rating agencies, namely the Economist Intelligence Unit, Euromoney, Institutional Investor, International Country Risk Guide, Moody's, Political Risk Services, and Standard and Poor's. These risk rating agencies employ different methodologies and methods to determine country risk ratings, combining a wide range of qualitative and quantitative information regarding alternative measures of economic, financial and political risk into associated composite risk ratings. A primary function of country risk assessment is to anticipate the possibility of debt repudiation, default or delays in payment by sovereign borrowers (Burton and Inoue, 1985).

However, the accuracy of any risk rating agency with regard to any or all country risk measures is open to question. For purposes of evaluating the importance and relevance of agency country risk ratings, it is necessary to analyse such agency rating systems according to established rating criteria. The primary purpose of each of these rating agencies is to measure the risk associated with investing in a foreign country.

This paper provides a qualitative comparison of country risk rating systems used by Economist Intelligence Unit (EIU), Euromoney, Institutional Investor (II), International Country Risk Guide (ICRG), Moody's, Political Risk Services (PRS), and Standard and Poor's (S\&P's). A classification of the seven risk rating agencies is given according to the agency definition of country risk ratings, number of countries covered, frequency of the risk ratings, number and type of ratings compiled, number and type of risk component variables used, weights assigned to risk components, and the given range for the risk ratings.

\section{COUNTRY RISK LITERATURE}

For purposes of evaluating the accuracy of agency risk rating systems, it is also necessary to review the literature relating to empirical country risk models. Hoti (2002) reviewed 50 empirical studies on country risk that had been published over the last two decades. The studies were analysed according to established statistical and econometric criteria used in estimation, evaluation, and forecasting in order to evaluate the practicality and relevance of the economic, financial and political theories pertaining to country risk.
Table 1 classifies the 50 studies according to the type of country risk variable used. Of the 50 studies, 27 examined debt rescheduling on 36 occasions, 17 considered country risk ratings on 18 occasions, and 6 considered other types of dependent variables [see Hoti (2002) for the definitions of these three types of variables].

Table 1: Type of Dependent Variable Used

\begin{tabular}{lc}
\hline Type & Frequency \\
\hline Debt rescheduling & 27 \\
Agency country risk ratings & 17 \\
Others & 6 \\
\hline TOTAL & 50 \\
\hline
\end{tabular}

Although debt rescheduling is the most frequently used dependent variable in the country risk rating literature, this paper focuses on the agency country risk ratings, which is the second most frequently used variable in the literature [for further details, see Hoti and McAleer (2002)]. A country risk rating is primarily a measure of country creditworthiness. The higher the country creditworthiness, the higher the associated risk in investing in a country, and the higher the probability that the country will reschedule its future debt payments.

Table 2 classifies the rating agencies used in the 17 country risk studies according to their frequency. Institutional Investor country risk ratings are the most frequently used ratings, and were used 13 times in total. Euromoney country risk ratings, which were used 6 times, are the second most frequently used ratings. Moody's, S\&P's, and ICRG country risk ratings were each used twice, followed by EIU and PRS, each being used once.

Table 3 reports four types of risk component variables used in the 17 country risk ratings studies, namely economic, financial, political, and

Table 2: Agency Ratings Used

\begin{tabular}{lc}
\hline Agency & Frequency \\
\hline II & 13 \\
Euromoney & 6 \\
Moody's & 2 \\
S\&P's & 2 \\
ICRG & 2 \\
EIU & 1 \\
PRS & 1
\end{tabular}

Note: Some studies used data from more than one agency. 
composite. Composite risk variables are ratings or aggregates that comprise economic, financial and political risk component variables, and were used in all 17 studies. Of these studies, only two did not use economic variables and only one did not use financial variables. Political variables have been used less frequently, namely in 10 studies.

Table 3. Risk Component Variables Used in Country Risk Ratings

\begin{tabular}{lc}
\hline Variables & Frequency \\
\hline Economic & 15 \\
Financial & 16 \\
Political & 10 \\
Composite & 17 \\
\hline Number of Studies & 17 \\
\hline
\end{tabular}

Table 4 presents the number of country risk components used, as well as their frequency. All four country risk components have been used in 10 studies, 4 studies used variables representing three risk components, 3 studies used variables representing two risk components, and no study used variables representing only one risk component.

Table 4. Frequency of Risk Component Variables Used in Country Risk Ratings

\begin{tabular}{cc}
\hline Risk Components Used & Frequency \\
\hline 4 & 10 \\
3 & 4 \\
2 & 3 \\
1 & 0 \\
\hline Total & 17 \\
\hline
\end{tabular}

\section{COMPARISON OF COUNTRY RISK RATING METHODOLOGIES}

Country risk refers broadly to the ability and willingness of a country to repay its financial obligations to its foreign creditors. While the individual agencies use different definitions of country risk ratings, they all fall into this broad category.

Institutional Investor and Euromoney define their country risk ratings as measures of the creditworthiness of a country as a whole. These ratings measure the economic, financial, and political performances of countries. Moody's country risk rating is defined as a measure of the ability and willingness of a country's central bank to provide foreign currency to service the foreign debt held by the government and other borrowers residing in that country. This rating is not a direct evaluation of the creditworthiness of the government, but rather an assessment of the foreign liabilities of the country as a whole. Unlike Moody's, S\&P's defines its country risk rating as a measure of a government's ability and willingness to repay debt according to its terms. Standard and Poor's ratings are sovereign ratings as they address the credit risk of the government and not of the other borrowers of a country (Howell, 2002). The ICRG country risk rating is defined as the ability and willingness of a country to finance its official, commercial, and trade debt obligations. It measures the economic, financial and political structures of a country as a whole. Similarly, the EIU defines its country risk rating as a measure of the likelihood of a financial crisis in a country that would affect foreign investors in that country. The Economist Intelligence Unit ratings also provide a measure of the general risk associated with investing in a country. Finally, PRS defines its rating as a measure of the likely changes in the level of political turmoil and government intervention that affect the business climate. These ratings are known as forecast ratings.

Table 5 classifies the seven rating agencies according to the year they started to compile country risk ratings. Clearly, Moody's and S\&P's are the oldest agencies in the risk rating industry.

Table 5: Risk Ratings Debut Year

\begin{tabular}{lc}
\hline Agency & Year \\
\hline Moody's & 1914 \\
S\&P's & 1941 \\
II & 1979 \\
PRS & 1979 \\
Euromoney & 1983 \\
ICRG & 1984 \\
EIU & NA \\
\hline
\end{tabular}

Note: "NA" denotes "Not Available".

Moody's issued its first country risk ratings just before World War I. Standard and Poor's was formed after Poor's Publishing and Standard Statistics merged in 1941. Like its predecessors, S\&P's continued to compile risk ratings for several sovereign bond issues (Bhatia, 2002). While II and PRS risk ratings debuted in 1979, Euromoney published its first ratings in 1983, followed by ICRG in 1984. The debut year for EIU country risk ratings are not available. 
Table 6: Classification by the Number of Countries Covered

\begin{tabular}{lc}
\hline Agency & Number of Countries \\
\hline Euromoney & 185 \\
ICRG & 140 \\
II & 135 \\
Moody's & 109 \\
EIU & 100 \\
PRS & 100 \\
S\&P's & 93 \\
\hline
\end{tabular}

In Table 6, the seven rating agencies are classified according to the number of countries rated, as of February 2003, except for Moody's and S\&P's, for which the information is available to July 2002. The number of rated countries ranges from 93 to 185. Of the seven rating agencies, Euromoney's coverage is the largest, compiling ratings for 185 countries. The ICRG covers the second largest group of countries with 140, while II provides ratings for more than 135 countries (Howell, 2002).

Table7: Classification by Frequency of Ratings

\begin{tabular}{lc}
\hline Agency & Frequency of Ratings \\
\hline ICRG & Monthly \\
EIU & Quarterly $^{*}$ \\
PRS & Quarterly \\
II & Semi-annual \\
Euromoney & Semi-annual \\
Moody's & Annual $^{*}$ \\
S\&P's & Annual $^{* *}$ \\
\hline
\end{tabular}

* with monthly ratings updates.

${ }^{* *}$ with weekly ratings updates.

As of July 2002, Moody's and S\&P's have been providing ratings for 109 and 93 countries, respectively (Bhatia, 2002), with S\&P's having the smallest country coverage in the group. Virtually every one of the countries covered by Moody's participates in the world's capital markets. Both EIU and PRS provide ratings for 100 countries. The EIU covers key emerging and highly indebted countries that are monitored by the its Country Risk Service (CRS).

Published country risk ratings are made available on a monthly, quarterly, semi-annual, and/or annual basis. Table 7 classifies the seven rating agencies according to the frequency of their ratings. Of the seven rating agencies, ICRG is the only agency to provide consistent country risk ratings on a monthly basis. The Economist
Intelligence Unit publishes quarterly risk ratings with monthly updates on these ratings. Political Risk Services provides quarterly ratings with no updates, while II and Euromoney publish their ratings semi-annually in the March and September issues of these monthly magazines. Moody's and S\&P's provide annual credit reports with monthly and weekly ratings updates, respectively.

Table 8 classifies the seven rating agencies according to the number of risk ratings they compile. The number of agency compiled ratings ranges from 1 to 10 . It should be emphasised that while Moody's and S\&P's compile ratings for both the issuer and specific debt instruments, the other five agencies compile ratings only for the issuer. Of the 39 risk ratings, more than half are compiled by Moody's and Euromoney, with the remaining 19 ratings being compiled by S\&P's, ICRG, EIU, PRS, and II.

Table 8: Classification by Number of Ratings Compiled

\begin{tabular}{lc}
\hline Agency & Number of Ratings \\
\hline Moody's & 10 \\
Euromoney & 10 \\
S\&P's & 7 \\
ICRG & 4 \\
EIU & 4 \\
PRS & 3 \\
II & 1 \\
\hline Total & 39 \\
\hline
\end{tabular}

For each nation, Moody's publishes ratings in ten major areas, namely long-term (bonds and preferred stock), issuer, bank deposits, bank financial strength, national scale, managed fund, real estate fund, prime rating, and speculative grade liquidity. Moody's country risk ratings act as sovereign ceilings or caps on ratings of foreign currency securities of any other borrowing entity. The ratings account for foreign currency transfer risk and systemic risk in the nation. Like Moody's, Euromoney offers ten ratings for each country it covers. These ratings include one composite country risk rating and nine component risk ratings, namely political risk, economic performance, debt indicators, debt in default or rescheduled, credit ratings, access to bank finance, access to short-term finance, access to capital markets, and discount on forfeiting. Standard and Poor's ratings are provided for seven major areas, namely long-term debt, commercial paper, preferred stock, certificates of deposit, money market funds, mutual bond funds, and the claimspaying ability of insurance companies. Such ratings set the benchmark for the ratings assigned 
to other issuers in the country. International Country Risk Guide and EIU compile four types of risk ratings each. International Country Risk Guide ratings include one composite country risk rating and three component risk ratings, namely economic, financial and political. The Economist Intelligence Unit compiles one country risk rating and three specific investment ratings, namely currency risk (associated with accepting foreign exchange exposure against the US dollar), sovereign debt risk (associated with foreign currency loans to sovereign states), and banking sector risk (associated with foreign currency loans to banks). Political Risk Services offers three industry forecasts at the micro level, namely financial transfers (banking and lending), foreign direct investment (such as retail, manufacturing, and mining), and exports to the host country market. Finally, II offers only one risk rating, which is the country risk rating.

Table 9: Number of Risk Component Variables Used

\begin{tabular}{l|ccccc}
\hline Agency & ECO & FIN & POL & Others & Total \\
\hline EIU & 55 & 10 & 11 & 0 & 76 \\
Euromoney & 2 & 10 & 11 & 3 & 26 \\
ICRG & 5 & 5 & 12 & 0 & 22 \\
PRS & 13 & 2 & 5 & 0 & 20 \\
Moody's & 7 & 0 & 6 & 0 & 13 \\
S\&P's & 3 & 1 & 6 & 0 & 10 \\
II & 5 & 3 & 1 & 0 & 9 \\
\hline
\end{tabular}

Note: Economic, financial and political risk ratings are denoted as ECO, FIN, and POL, respectively. The "Others" category refers to agency ratings.

Table 9 classifies the seven rating agencies according to the total number of risk component variables. The total number of risk component variables used in the rating systems of the seven agencies ranges from 9 (for II) to 76 (for EIU). Euromoney, ICRG and PRS use at least 20 component variables to compile their ratings, while Moody's and S\&P's use at least 10 component variables. In terms of the individual risk component variables, the number of the economic risk variables used by each agency varies from 2 (for Euromoney) to 55 (for EIU). EIU uses the largest number of the economic risk variables, followed by PRS (13 variables), Moody's (7 variables), ICRG and II (5 variables, each), S\&P's (3 variables), and Euromoney (2). In the case of financial risk variables, the total number of variables used by each agency ranges from 0 (for Moody's) to 10 (for EIU and Euromoney). Of the remaining four agencies, ICRG uses 5 financial variables in total, followed by II, PRS, and S\&P's, which use 3, 2, and 1 financial risk variables, respectively. The number of political risk variables used by each agency ranges from 1 (for II) to 12 (for ICRG). Of the remaining five agencies, EIU and Euromoney both use a total of 11 political variables, and are followed by Moody's and S\&P's (with 6 variables each) and PRS (5 variables). Finally, regarding the "Others" category, which refers to agency risk ratings, Euromoney is the only agency which considers risk ratings compiled by 3 other agencies, namely Moody's, S\&P's, and Fitch IBCA.

Table 10: Type of Risk Component Variables Used

\begin{tabular}{lc}
\hline Variables & Frequency \\
\hline Economic & 90 \\
Political & 52 \\
Financial & 31 \\
Others & 3 \\
\hline Total & 176
\end{tabular}

Note: The "Others" category refers to agency risk ratings.

The classification in Table 10 is given according to the type of risk component variables being used in the rating systems of the seven rating agencies. More than half of the risk component variables used by the seven risk rating agencies are predominantly economic in nature, with the remainder being political or financial in nature. Political variables are the second most frequently used risk components. The "Others" category refers to agency risk ratings, being used only in the case of the Euromoney risk rating system.

In terms of the rating system used to compile composite country risk ratings, EIU, Euromoney, and ICRG differ from Moody's, S\&P's, PRS and II, in that they calculate composite ratings using specific formulae, with predetermined weights assigned to each of the risk components. Table 11 reports the risk component weights in the rating systems of EIU, Euromoney, and ICRG.

Referring to Table 11, the economic risk variables have the highest weight at $55 \%$ in the case of EIU, followed by Euromoney and ICRG, each assigning a weight of $25 \%$. For financial risk component variables, Euromoney assigns the highest weight at $40 \%$, followed by ICRG and EIU, assigning weights of $25 \%$ and $23 \%$, respectively. For the political risk component variables, ICRG assigns the highest weight at $50 \%$, followed by Euromoney and EIU with weights of $25 \%$ and $22 \%$, respectively. Finally, in order to obtain the overall country risk score, Euromoney assigns a weight of $10 \%$ to agency ratings component. 
Table 11: Weights Assigned to Risk Component Variables (in percent)

\begin{tabular}{l|ccccc}
\hline Agency & ECO & FIN & POL & Others & Total \\
\hline EIU & 55 & 23 & 22 & 0 & 100 \\
Euromoney & 25 & 40 & 25 & 10 & 100 \\
ICRG & 25 & 25 & 50 & 0 & 100 \\
\hline
\end{tabular}

Note: Economic, financial and political risk ratings are denoted as ECO, FIN, and POL, respectively. The "Others" category refers to agency ratings.

With respect to the rating systems of Moody's, S\&P's, PRS, and II, composite risk ratings are determined on a subjective basis. For each country, Moody's analysts weigh the risk component variables according to their assessment of the credit risk of the issuer. Similarly, in determining a risk rating, S\&P's analysts weight the risk component variables based on their perceptions of economic and fundamental business conditions for each country. PRS system compiles forecast ratings based on the component risk variables, and weighs them according to the assessed potential economic, financial and political risks to business investments and trade (Howell, 2002).

Institutional Investor differs from the other six agencies in that it uses no internal rating system. For each country, II asks 75-100 leading international banks to rate the risk components. The individual ratings are weighted using II's formula, with greater weights assigned to responses based on the extent of a bank's worldwide exposure and the degree of sophistication of a bank's country risk model. The names of the participating banks are kept strictly confidential (Howell, 2001). In the country risk literature, the II country risk assessment is known as the banker's judgment.

Table 12: Types of Risk Rating Grades

\begin{tabular}{lc}
\hline Agency & Grading Range \\
\hline II & 0 to 100 \\
Euromoney & 1 to 100 \\
ICRG & 0 to 100 \\
Moody's & Aaa to C \\
S\&P's & AAA to D \\
EIU & A to E \\
PRS & A + to D \\
\hline
\end{tabular}

Finally, in Table 12 the seven rating agencies are classified according to the type and range of gradings they assign to country risk ratings. Institutional Investor, Euromoney, and ICRG provide quantitative country risk ratings, which range from 0 (lowest) to 100 (highest). On the other hand, Moody's, S\&P's, EIU, and PRS publish qualitative letter ratings. The country risk ratings for Moody's, S\&P's, EIU, and PRS range from Aaa (highest) to C (lowest), AAA (highest) to $\mathrm{C}$ (lowest), A (highest) to $\mathrm{E}$ (lowest), and A+ (highest) to D (lowest), respectively. In all cases, the lower (higher) is a given risk rating, the higher (lower) is the associated risk.

\section{CONCLUDING REMARKS}

The paper provided a qualitative comparison of the country risk rating systems of seven leading commercial analysts of country risk, namely Institutional Investor, Euromoney, Moody's, Standard and Poor's, International Country Risk Guide, and Political Risk Services. Such an evaluation permitted a critical assessment of the importance and relevance of agency rating systems.

\section{ACKNOWLEDGEMENTS}

The author wishes to thank Michael McAleer for helpful comments and suggestions, and to acknowledge the financial support of an Australian Research Council PhD scholarship, the C.A. Vargovic Memorial Fund at UWA, and an Individual Research Grant from the Faculties of Economics \& Commerce, Education and Law at UWA.

\section{REFERENCES}

Bhatia, A.V., (2002) Sovereign Credit Ratings Methodology: An Evaluation, International Monetary Fund Working Paper 02/170.

Burton, F.N. and H. Inoue, (1985) An appraisal of the early-warning indicators of sovereign loan default in country risk evaluation systems, Management International Review, 25(1), 4556.

Hayes, N.L., (1998) Country risk revisited, Journal of Lending and Credit Risk Management, 80(5), 61.

Hoti, S., (2002) Snapshot Images of Country Risk Ratings: An International Comparison, in A. Rizzoli and A.J. Jakeman (eds.), Proceedings of the International Conference on Environmental Modelling and Software, Vol. 2, Lugano, Switzerland, 2002, pp. 532-537.

Hoti, S. and M. McAleer, (2002) Country Risk Ratings: An International Comparison, submitted.

Howell, L.D., (2001) The Handbook of Country and Political Risk Analysis, Third Edition, The PRS Group, New York. 